\title{
The Effect of Computer Assistance Learning Strategy on Learning Outcomes of Engineering Physics Viewed From Different Learning Styles
}

\author{
Wiwid Suryono, Mustaji, Andi Mariono \\ Study Program of Educational Technology \\ State Univesity of Surabaya \\ widsuryono@gmail.com
}

\begin{abstract}
This research aims to determine the effect of computer-assisted learning strategy on learning outcomes of engineering physics viewed from different learning style. Learning style is the way humans begin to concentrate, absorb, process and get new information. The use of information technology can facilitate the learning process so that it can improve learning outcomes. So that required computer-assisted learning strategy.

This study is a quasi-experimental type of experiment. The method chosen in this research is a quasi-experimental method with factorial design $3 \times 2 \times$ 2. The population used in this research is Taruna Akademi Engineering and Safety of Flight (ATKP) Surabaya.

Based on the result of data analysis, it can be concluded: (1) There is no difference in learning of physics technique between cadets which have a visual, auditorial and kinesthetic learning style. (2) There is no interaction between learning strategy and learning style to the result of physics learning.
\end{abstract}

Keywords-component; Computer Assistance Learning Strategy, Learning Outcomes of Engineering Physics, Learning Style.

\section{INTRODUCTION}

Studies conducted at the higher education level show that the user of information and technology has been achieved and innovative based on data from The Economist Intelligence Unit's Index of Democracy (2008). The study revealed that the use of digital technology in the campus environment has not been implemented until the practice of e-learning. Use of information technology in the learning process becomes an option, because using information technology that can facilitate the learning process, can improve learning outcomes. Computer-assisted learning (PBK) or computerassisted instruction (CAI) is a learning that can assist and support conventional learning strategies $\lceil 1\rceil$. Another factor that can affect learning outcomes is the learner's color [2]. To determine the educational strategy of one of the determining factors through the character of the learner can be seen from the learning style. In this research, as a novelty form of research, then another factor influencing computer strategy is to use learners' learning styles. In research conducted by Gilakjani [3] said that three learning styles of learners, namely visual, auditory, and kinesthetic.

The importance of new strategies applied and attention to the characteristics of learners in ATKP is based on a preliminary study of the results of observations and discussions with the lecturers of Technical Physics that the low learning outcomes of Physics In cadets caused by cadets are less involved in the learning process, where cadets are required to hear and memorize some basic materials physics of lecturers. This happens because lecturers still use teaching strategies that are teacher-centered. The application of teaching strategies that are a lecture by the lecturers makes the participation of cadets in learning relatively low. Most cadets tend to be able to mimic what the lecturer does. Taruna is unable to use textbooks effectively. Taruna tends to rewrite the existing concepts in textbooks, thus spending a lot of time and learning inefficient.

Arends [4]proposed a direct teaching strategy to put the lecturer as a teaching center in order to involve cadets directly as a process of providing experience and skills training taught step by step. To reduce the misconceptions of midshipmen and to guide the cadets in the formation of new concepts to be combined with the old concept, so that the concepts are interconnected to form a concept map. When associated with learning basic electrical materials, computerassisted learning provides an opportunity for cadets to analyze existing problems through the interpretation of electron theory, voltage, current strength, and electrical resistance.

Based on the results of preliminary observation, it is known that cadet style learning more that is visual, that is more attention and record teaching materials. While in cadets, tend to be more directed toward auditory and kinesthetic, that is more listening. Amri \& Ahmadi [5] defines Direct Instruction Model as one of the Learning model specially designed to develop learners learning about procedural knowledge and well-structured declarative knowledge and can be learned step by step tends to directly practice teaching materials. Even cadets are found that do not carry a notebook into the classroom or carry a notebook but 
the records are not complete. However, it can not be denied as well, it is found cadets who have a visual learning style, which is more attention to the material presented in writing and then re-recorded in the notebook.

This phenomenon ultimately has an impact on the achievement of cadets, because, in the evaluation of the achievements of physics learning, the cadets are not only required to understand the teaching material cognitively but also must include effective and psychomotor domains. Therefore, direct teaching strategies that have been widely applied in the classroom need to be evaluated in order to know whether the direct teaching strategy can accommodate the learning style of all cadets in achieving optimal learning outcomes.

\section{LITERATURE REVIEW}

\section{A. Computer-assisted Learning Study}

Computer Based Training (CBT) is considered the most powerful way to apply to independent learning strategies because by using CBT learners can look for shared literature courses and can practice directly by using the CBT application. besides of it, we can learn something from some software deliberately designed to provide convenience for someone to learn something to be studied (Daryanto, 2016) [6]. So by using CBT, the cadets can learn the physics techniques as well as practice using the software.

\section{B. Direct Learning Strategy}

of the teaching approaches specially designed to support learners' learning process related to declarative knowledge and well-structured procedural knowledge that can be taught with gradual, step-by-step pattern of activity.

Arends[7], which states that "The direct instruction model was specifically designed to promote student learning of procedural knowledge and declarative knowledge that is well structured and can be taught in a step-by-step fashion."

\section{Definition of Learning Styles}

Learning styles are the way people begin to concentrate, absorb, process and get new and difficult information, Rita \& Dunn, in Prashnig [8]. According to Nasution [9], "learning style or learning style is the way he reacts and uses stimuli he receives in the learning process". Sukadi (2008) defines that "learning style is a combination of one's way of absorbing knowledge and how to organize and process information or acquired knowledge".

\section{Definition of Learning Outcomes}

Learning outcomes are achievements obtained by learners after going through the learning process [10]. Sudjana [11] defines student learning outcomes as essentially behavioral changes as learning outcomes in a broader sense encompassing cognitive, effective, and psychomotor fields. According Hamalik [12]learning outcome is as a change of behavior in a person that can be observed and measured form of knowledge, attitude, and skills.

\section{E. Characteristics of Taruna ATKP}

Taruna ATKP is the daughter of the participants of the training for the establishment of diploma and non-diploma programs from high school graduates majoring in IPA or IPS, and or vocational graduates majoring in mechanics, electrical, building, informatics or electro, in accordance with the requirements determined to adjust the selected courses, study Diploma 3 for 6 semesters. With a minimum standard height of $155 \mathrm{~cm}$ for women and $160 \mathrm{~cm}$ for men and no glasses, no beta too, no morning pierced men and a maximum age of 23 years in September.

\section{F. Relevant Research}

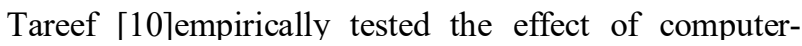
assisted learning on Statistics materials to learners, where the results show that significantly, achievement of students' statistical learning outcomes that implement computer-aided learning strategies is better than those that apply traditional learning strategies. Meanwhile, Kareem [13] tested the implementation of computer-assisted learning strategies on Biological materials, and the results showed that achievement of learning outcomes of Biology materials in learners with computer-assisted learning strategies is better than those that apply traditional learning.

A similar study was also conducted by Furo [14]which explains that the achievement of Chemistry learning outcomes by applying computer-assisted learning strategy is higher than the achievement of learning outcomes in direct learning.

Furo [14]recommends since this study shows that computers can improve the academic achievement of learners, all secondary schools in both private and public states should be encouraged to have their own computer laboratories, to enable them to reach higher levels of academic achievement, that they are theoretical in design, the use of CAI in education makes a significant contribution to the performance of higher learners in school.

\section{METHOD}

This study is a quasi-experimental type of experiment because all the variables that are likely to affect the treatment and learning outcomes are unlikely to be controlled. This quasi-experimental study aims to examine the effect of the independent variables on the bound variables. In this study Taruna / Taruni ATKP as the subject of research, while the learning strategy is the treatment of research given to the subject. Quasi-experiments are performed because not all influential variables can be strictly controlled like pure experiments in the laboratory. Randomly grouping subjects and reorganizing existing classes is not possible.

The method chosen in this research is a quasiexperimental method with factorial design $3 \times 2 \times 2$. The factorial design used adopt from theory Dowdy et al (2004) which states that the factorial design into three combinations aimed to test the interaction. The research was designed in which three variables were manipulated at the same time to 
study the effects caused by the interaction of several variables. The center of this study is on the independent variable, as it will be assessed for either its effects or effects separately, as well as collectively. Both independent variables are manipulated.

The population used in this research is Taruna Akademi Engineering and Safety of Flight (ATKP) Surabaya. At ATKP Surabaya there are Department of Flight Engineering and Aviation Safety Department which is in charge of a technical physics course.

In this study using the sample to represent the population is the Taruna Aviation Engineering Department which has certain criteria to support the research.

The subject of research according to Amirin [15] is someone or something about it to obtain information. The description in question is the description that will be used as data in supporting the research. From the data table above, the subject of the research is 3 classes of cadets of study program D.3 Electrical Engineering Airport of Generation XI A, B and D.3 Telecommunication Engineering and Air Navigation of 72 people as experimental class and 3 cadets class of study program D.3 Aircraft Engineering Air Force II-A, B and C number 72 people as control class.

The subject of research according to Amirin [15] is someone or something about it to obtain information. The description in question is the description that will be used as data in supporting the research. From the data table above, the subject of the research is 3 classes of cadets of study program D.3 Electrical Engineering Airport of Generation XI A, B and D.3 Telecommunication Engineering and Air Navigation of 72 people as experimental class and 3 cadets class of study program D.3 Aircraft Engineering Air Force II-A, B and C number 72 people as control class.

\section{RESULTS AND RESEARCHDISCUSSION}

\section{A. The Description of Data and The Result of Study Inquiry}

Data on learning style questionnaire results were given to cadets in six classes, of which three classes of experimental groups and three classes of control groups totaled 144 cadets with details of 72 cadets of experimental groups implementing computer-assisted learning strategies (PBK) and 72 cadets of control groups implementing a direct learning strategy. In the experimental class (PBK) each learning style is described as follows: (1) Taruna that has visual learning style of 43 cadets with the highest score 21 and the lowest score 9. (2) Taruna having auditorial learning style totaled 13 cadets with the highest score 24 and the lowest score 5. (3) Taruna who has kinesthetic learning style numbered 16 cadets with the highest score 22 and the lowest score 6.
B. Differences in Learning Results Concepts of Engineering Physics Between Taruna Learning Process Using Direct Learning Strategy with Computer Assisted Learning Strategy at ATKP Surabaya

Implementation of computer-assisted strategy in learning physics engineering on Surabaya flight polytechnic which is a boarding school, in giving time in thought still not given maximally. And the lecturer still has not shown the role to model the material of engineering physics. The cadets still have not been able to organize themselves in learning. Selfregulation related to the understanding of cadets can demonstrate in making both series and parallel series.

C. Differences in learning physics techniques between cadets who have visual, auditorial, and kinesthetic learning styles at ATKP Surabaya

Learning styles are divided into three, visual, auditorial and kinesthetic. The learning styles that cadets possess are very influential in learning something with a common approach (Oxford, 2003). The results of this study indicate that there is a very significant difference in the results of physics learning cadets techniques both visually, auditorial and kinesthetic. In this study the number of cadets who have visual learning styles more than with auditorial and kinesthetic. Among the three learning styles, cadets who have visual learning styles have better learning outcomes than cadets who have auditorial and kinesthetic learning styles.

D. The interaction between learning strategy and learning style of physics technique at the Academy of Engineering and Flight Safety (ATKP) Surabaya

The result of learning physics material at cadet ATKP Surabaya is related to learning strategy with learning style to cadets learning the result. Engineering physics is a science that strongly supports the achievement of cadet competence standards related to electrical engineering. The course of engineering physics is one of the theories based on theory and practice so that it relates to the concept and procedural. Learning strategy is divided into two namely direct learning strategy and computer-assisted learning strategy. Amri \& Ahmadi [5]defines.

Every interaction between learning strategy and learning style, problem-based learning interaction with visual learning style (PBM-Vl), learning problem with auditory learning style (PBM-A), problem-based learning with kinesthetic learning style (PBM-K), Teaching directly with visual learning style $(\mathrm{PL}-\mathrm{V})$, direct instruction with auditory learning style (PL-A), direct teaching with kinesthetic learning style (PL-K) gives different influence to the result of physics learning technique. This can be said, as discussed above that a direct learning strategy with a separate visual learning style can improve the cadets' learning outcomes. The combination of problem-based learning strategies with visual learning styles is a learning strategy and learning styles that can reinforce each other. 
Learning style with learning result of physics technique of Sig value. Calculate (3.66)> 0.05 then thank Ho. Coefficient results. Calculate $(3,66)>0,05$ then thank Ho. While the result of coefficient F Count (1.011) $<F$ table $(2,28)$ hence accept Ho, conclusion there is no difference of learning result of physics concept of technique between cadets having a visual, auditorial and kinesthetic learning style.

Learning style with the result of learning physics technique sig value. Calculate $(0.825)>0.05$ then thank Ho. While the coefficient value F Count $(0.193)<\mathrm{F}$ table $(2.28)$ then accept Ho. In conclusion, there is no difference in procedural learning result of technical physics between cadets having visual, auditorial and kinesthetic learning styles.

The third conclusion from the above two paragraphs expression that there is no difference between conceptual learning result and procedural learning result of physics technique between cadets having visual, auditorial and kinesthetic learning styles.

Furthermore, testing criteria of interaction between learning strategies to conceptual learning outcomes used in this study are the coefficient sign. Calculate $(.142)>0.05$ then accept Ho and coefficient F Count (1.980) $<$ F table $(2,28)$ then accept Ho. In conclusion, there is no interaction between learning strategies to the results of physics learning techniques.

While the criteria of interaction testing between learning styles on learning outcomes are sig coefficient. Calculate $(.786)>0.05$ then accept Ho and coefficient $\mathrm{F}$ Count $(0.241)<F$ table $(2.28)$ then accept Ho. In conclusion, there is no interaction between learning styles to the results of physics learning techniques.

Thus the fourth conclusion is that there is no interaction between learning strategy and learning style to the result of physics learning technique.

\section{ACKNOWLEDGMENT}

Learning styles are a way of reacting and using stimulants that are accepted in the learning process of Nasution [9]. Each learner has unique characteristics of each other. In accommodating the learners' learning styles, Kaufhold (2002), at least mentions the four roles of the lecturers of ATKP as educators acting as informants, disciplined educators, educators as mentors, and educators as sources.

\section{REFERENCES}

[1] D. A. Jacobsen, P. Eggen, and D. Kauchak, "Methods For Teaching Metode-metode Pengajaran Meningkatkan belajar siswa TK-SMA," Yogyakarta: Pustaka Pelajar, 2009.

[2] C. M. Reigeluth, Instructional design theories and models: An overview of their current status. Routledge, 2013.

[3] A. P. Gilakjani, "Visual, auditory, kinesthetic learning styles and their impacts on English language teaching," J. Stud. Educ., vol. 2, no. 1, pp. 104-113, 2011.

[4] R. Arends, Classroom instruction and management. McGraw-Hill Companies, 1997.

[5] S. Amri and I. K. Ahmadi, "Proses Pembelajaran Kreatif dan Inovatif Dalam Kelas," Jakarta: Prestasi Pustaka, 2010.

[6] D. Daryanto, "Media pembelajaran: Peranannya sangat penting dalam mencapai tujuan pembelajaran," Yogyakarta Gaya Media, 2010.

[7] R. Arends and S. Castle, Learning to teach, vol. 2. McGraw-Hill New York, 1991.

[8] B. Phrasnig, "The Power of Learning Styles: Memacu Anak Melejitkan Prestasi dengan Mengenal Gaya Belajarnya, terj," Nina Fauziah, Bandung Mizan Pustaka, 2007.

[9] S. Nasution, Didaktik asas-asas mengajar. Bumi Aksara, 1995.

[10] A. Bin Tareef, "The effects of computer-assisted learning on the achievement and problem solving skills of the educational statistics students," Eur. Sci. Journal, ESJ, vol. 10, no. 28, 2014.

[11] N. Sudjana, Penilaian hasil proses belajar mengajar. PT Remaja Rosdakarya, 1995.

[12] O. Hamalik, Proses belajar mengajar. Bumi Aksara, 2004.

[13] A. A. Kareem, "Effects of Computer Assisted Instruction on Students' Academic Achievement and Attitude in Biology in Osun State, Nigeria," J. Emerg. Trends Educ. Res. Policy Stud., vol. 6, no. 1, pp. 69-73, 2015.

[14] P. T. Furo, "Computer assisted instruction (CAI) and students' interest as determinant of SS II chemistry students' achievement in chemical equilibrium in Rivers State," IOSR J. Appl. Chem. (IOSRJAC).[Online], vol. 8, no. 8, pp. 50-56, 2015.

[15] T. M. Amirin, Menyusun rencana penelitian. PT Raja Grafindo Persada, 2000. 